Transportation Research Forum

Airline Financial Distress and Customer Satisfaction

Author(s): Dina Ribbink, Christian Hofer, and Martin Dresner

Source: Journal of the Transportation Research Forum, Vol. 48, No. 1 (Spring 2009), pp. 89-104

Published by: Transportation Research Forum

Stable URL: http://www.trforum.org/journal

The Transportation Research Forum, founded in 1958, is an independent, nonprofit organization of transportation professionals who conduct, use, and benefit from research. Its purpose is to provide an impartial meeting ground for carriers, shippers, government officials, consultants, university researchers, suppliers, and others seeking exchange of information and ideas related to both passenger and freight transportation. More information on the Transportation Research Forum can be found on the Web at www.trforum.org. 


\title{
Airline Financial Distress and Customer Satisfaction
}

\author{
by Dina Ribbink, Christian Hofer, and Martin Dresner
}

An investigation is conducted on the effect of financial distress on customer service levels in the U.S. airline industry. Using data from the first quarter of 1998 to the third quarter of 2006, we employ a seemingly unrelated regressions (SUR) model to analyze the impact of financial distress on three measures of customer service. We find that higher financial distress is associated with better ontime performance of airlines and fewer lost bags. The relationship of airline financial distress to the number of bumped customers, however, is insignificant.

\section{INTRODUCTION}

Many companies in the United States are facing issues due to financial distress. In 2005, over two million companies filed for bankruptcy (American Bankruptcy Institute 2006), while many more had financial difficulties. According to Dothan (2006), financial distress can lead to a loss in market share, decreases in productivity, reductions in capital expenditures, and even to the sale of assets at depressed prices.

The reasons for financial distress are manifold, and can span from mismanagement of assets, to economic downturns, to a lack of customer focus. Financial distress is also likely to affect a company's dealings with its customers. Firms operating under financial pressure are often forced to change tactics. Generally, these businesses are faced with two distinct choices - to cut costs or to increase revenues or a combination of the two. Cost cuts - especially in wages - may result in dissatisfied employees leading to less than optimal performance which, in turn, can easily translate into lower customer service levels. Alternatively, companies can attempt to increase their revenues, for example, by focusing on improving customer service to retain and attract customers. Either approach - cost cutting or revenue enhancement - can be directly linked to changes in customer service management.

Customer service is a firm decision variable that measures the relationship between the final customer and a firm. It refers to the extent to which a company is able to meet customer expectations and needs, and is of strategic importance to profit maximizing organizations. Customer service implies that businesses strive to "continually enhance customer experience and satisfaction, to deliver quality in a competitive marketplace" (Spencer-Matthews and Lawley 2006, p. 218).

An example of the effect of financial distress on customer service comes from the airline industry. US Airways filed for bankruptcy protection in September 2004. As a result of its financial difficulties, US Airways reduced costs by laying off employees (Anonymous 2002, 2005). However, these labor reductions contributed to US Airways' "Valentine's Day Massacre:" After the snowstorm on Valentine's Day, 2007, thousands of misplaced and stranded bags in Philadelphia resulted in upset customers across the country (Schlossberg 2007). Contributing to this service failure was a lack of motivated employees due to salary cuts for long-term employees and low starting salaries for new hires (Belden and McCoy 2006).

In contrast, CERT is an example of a company that used improved customer service as a means to combat financial distress (Lainas 1999). By the mid-'90s, this British third party logistics provider (3PL) faced severe financial conditions. A new management team introduced the goal of providing exceptional customer service, and ingrained customer service into the company's mission. Since 
1995, the company has grown tremendously and still states on its website its goal is to provide "the highest levels of customer service at no compromise!" (CERT 2007).

These two examples show the different ways financial distress can impact a firm's business conduct; specifically, its approach to customer service. It is this relationship between financial distress and customer service that is the focus of this paper. While previous research has examined how customer service impacts financial performance (e.g. Behn and Riley 1999, Dresner and Xu 1995, Ittner and Larcker 1998), research investigating the opposite relationship is scarce. This study, therefore, adds to the literature by addressing this issue; that is, how a firm's financial distress impacts customer service.

The paper provides new insights for both academia and business professionals about the impact of financial distress on customer service. To the authors' knowledge, this research is the first to demonstrate, empirically, the reaction of firms in the airline industry to financial distress and the effect of financial distress on customer service. The findings of this study can be used to guide companies experiencing financial distress in their approach to customer service. This research can direct managers to better understand industry practices and, hence, help them focus their customer service efforts in turning their firms around in times of financial distress.

The next section provides an overview of the literature in the fields of customer service and financial distress. The proposed relationship between financial distress and customer service is discussed, resulting in the development of our research hypotheses. In Section Three, the methodology of this study is explained in detail. The fourth section presents the findings of the regression analysis. Finally, Section Five provides our conclusions.

\section{LITERATURE REVIEW}

Companies in today's economy have long realized the potential for providing good customer service. It is considered one of the major determinants of competitive advantage. According to Parasuraman (1998), customer service supplements a company's core offering and entails an organization's ability to deliver customer needs and requirements. A common metaphor in this context is the "flower of service." The actual product or service is seen as a flower with petals (Lovelock 1994). The deliverable is the center of the flower while the petals present elements of customer service.

Companies intending to stay competitive must compete for customers and market share. Several studies have investigated the relationship between customer service and firm performance (e.g. Wiles 2007). Heskett et al. (1994) developed a model called the 'Service-Profit-Chain' that hypothesized that customer service leads from satisfaction to loyalty and eventually to profits. Customer satisfaction, resulting from good customer service, is of major importance in customer loyalty (Ellinger, Daugherty, and Plair 1999) and hence repeat purchases (Suzuki 2000). Satisfied customers will spread the word, and positive word-of-mouth is vital for most service companies (Dick and Basu 1994). Generally, this research stream finds support for a positive relationship between customer service and firm performance indicating that better customer service translates into better financial performance.

Financial distress and its outcomes are of major importance for companies, as it impacts their ability to conduct business, as well as to interact with customers and suppliers. Several studies (e.g. Routledge and Gadenne 2000) have established an empirical link between financial solvency and long-term operations. On the other hand, companies operating under financial distress are often faced with tough (re)negotiations, both with banks (for loans) and suppliers (Evans and Koch 2007). Banks generally charge higher interest rates to financially distressed organizations in order to account for the added risk for recouping their investments. Similarly, suppliers who sell to the distressed firm regularly require more restrictive terms of payment. In addition, customers may be more reluctant to engage in relationships with financially distressed companies. The main motivation for these actions is the increased risk of purchasing from a financially distressed firm; for example, a warranty 
does not carry the same reassurance; potential production disruptions; and the threat of finding a replacement supplier in case the company is liquidated.

Financial performance and financial distress have been widely investigated in the literature. Generally, financial performance is measured by such factors as the market value of equity (e.g. Ittner and Larcker 1998), the market share of the firm (Lambert and Sterling 1987), or the ratio of operating revenue to operating expenses of a company (Dresner and Xu 1995). Financial distress has been operationalized by reversing Altman's Z-score, a measure of the company's financial health (e.g. Hofer, Dresner, and Windle 2005).

In order to avoid financial distress, it is often necessary for companies to provide high levels of customer service. This may be especially true for companies operating in the service sector, such as the airline industry. An early examination of customer service in the airline industry was by Gourdin and Kloppenburg (1991), who determined a set of service quality criteria. The authors distinguished between the perspectives of passengers, airlines, and governmental officials, and identified dimensions in which the three overlapped or differed. These dimensions included convenience in departure and arrival times, meaningful flight information, and on-board comfort. Using questionnaire surveys, more recent studies have compared the SERVQUAL ${ }^{1}$ model to these airline-specific factors (e.g. Cunningham, Clifford, and Lee 2004). Industry-specific measures of customer service have been grouped into a number of categories, such as baggage handling, bumping procedures, operations and safety, in-flight comfort, and the ease of connections (Cunningham and Lee 2002).

Another stream of research in the airline industry uses objective service performance data, rather than customer perceptions, to determine customer service levels. The Air Travel Consumer Report, issued monthly by the U.S. Department of Transportation, reports on actual performance data, notably the percentage of flights arriving on-time (within 15 minutes of scheduled arrival), the number of mishandled baggage reports, and the number of filed customer complaints. Studies have used one or more measures from this report to assess the performance of airlines (e.g. Mazzeo 2003). Overall, it is generally agreed that the Airline Consumer Reports provide an objective (if incomplete) measure of customer service levels.

Financial distress has been an important subject in airline industry research, given the financial problems experienced by airlines. The airline industry's economic development has been especially volatile since the deregulation of the U.S. airline industry in 1978 (Gritta, Chow, and Freed 2003). Over the past 25 years, more than 140 airlines have filed for bankruptcy protection, sometimes resulting in the stabilization of the firm's health, while other times forcing the airline out of business (Gritta, Adrangi, Davalos, and Bright 2006).

A well-established measure for firm financial health used in airline industry research and elsewhere is Altman's Z-Score. It consists of several ratios that are weighted and combined into an overall measure of a firm's financial health. Originally derived for manufacturing companies (Altman 1968), it was later adjusted to apply to service industries as well (Altman 2002). As noted, a number of authors have used Altman's Z-Score in assessing the health of airlines. For example, Chung and Szenberg (1996) employed Altman's Z-Score as a measure of airline financial stability in the years following deregulation. Hofer et al. (2005) used a rescaled Altman's Z-Score as a measure of financial distress to test and support their hypothesis that airlines operating under bankruptcy, on average, charge lower ticket prices.

Very little work, however, has related financial distress to customer service in the airline industry. Borenstein and Rose (2003) have been the most explicit in their findings that "bankruptcy induces modest declines in service levels" in airlines. There is, however, a substantial amount of literature on actions firms may take to overcome financial distress and avoid corporate failure; i.e., 'turnaround' strategies (Hofer 1980, Smith and Graves 2005). These strategies stress the importance of strategic and operational change.

The first approach of turnaround strategies is generally to cut costs (Pearce and Robbins 1994, 1993). Labor costs are often a large percentage of expenditures for firms and reductions in the 
number of employees and/or cuts in pay can provide relief to financially distressed companies. However, these kinds of cost cuts may introduce uncertainties into the work environment and, as a consequence, result in lower employee satisfaction and commitment (Smith and Graves 2005). In turn, this is likely to cause a decline in customer service levels. Having fewer employees for the same amount of work may translate into overworked and/or underpaid workers who are less likely to perform according to expected standards. As well, a distressed company's workers may search for new positions in a more secure work environment (Smith and Graves 2005). Finally, employee turnover at distressed firms may lead to an outflow of tacit knowledge resulting in the loss of process and operating capabilities. Hence, it can be argued from the literature that financial distress will contribute to lower customer service levels.

The second approach of a financially distressed company's turnaround strategy relates to firm recovery (Robbins and Pearce 1992). Companies that are operating in financially stable situations are generally "bound by habits, procedures, and unreflective practices" (Grinyer and McKiernan 1990, p. 132) and hence may find no need to change the manner of their operations. In contrast, a company operating under financial distress may need to alter its course to increase revenues and hence profits (Pearce and Robbins 1993).

There are a number of ways a firm can increase revenues; i.e. raise prices, increase sales of existing products, and develop new products. A financially distressed firm may not have the financial capabilities to develop new products, but may seek to expand revenues by retaining and building its customer base. Customer service and, hence, satisfaction are major determinants of customer loyalty (Ellinger et al. 1999) and, as a consequence, repeat purchases (Suzuki 2000). Furthermore, satisfied customers will spread the word about a company, and positive word-of-mouth may result in additional customers (Dick and Basu 1994). Hence, it can be argued that financial distress may trigger a company to invest in better customer service.

Note that these two streams in the turnaround literature argue in opposite directions. While one stream suggests that financial distress leads to lower customer service, it is also possible that financially distressed firms actually increases customer service (the second stream). Using data from the U.S. airline industry, we provide an analysis of the impact of financial distress on customer service.

\section{METHODOLOGY}

\section{Airline Industry}

The relationship between financial distress and customer service is investigated using data from the airline industry, including the Air Travel Consumer Reports. The airline industry is a good industry to analyze the research question at hand for a number of reasons. First, the airline industry is one of the largest service fields in the U.S. economy. Second, since the second half of 2005, almost $50 \%$ of all U.S. commercial passenger aircraft have been operated by airlines that have filed for bankruptcy. Hence, the industry has experienced severe financial distress. Third, airlines are generally very specialized in the services they provide resulting in a very clearly defined industry. Finally, there are specific reporting regulations for airlines resulting in relatively complete, publicly available data sets.

\section{Data}

The data for the customer service measures are extracted from the monthly Air Travel Consumer Reports (ATCR) (2007). ATCR provides detailed reports of on-time performance of domestic U.S. carriers, the number of misplaced bags, the number of bumped customers (ticket over-sales) as well as the number of customer complaints. The data are provided on a monthly or quarterly basis. For the purpose of this analysis, all data are averaged on a quarterly basis. 
This dataset is complemented with quarterly, company-specific information from the Intermodal Transportation Database provided by the Bureau of Transportation Statistics (BTS 2007). BTS provides detailed information about carrier balance sheets and operating statements. Additionally, the Office of Aviation Analysis provides Airline Quarterly Financial Reviews (2007) that include information about various operating and financial statistics of U.S. airlines.

The final data set consists of a panel that includes information over a period of 23 quarters for more than 20 airlines. The customer service specific information is available from second quarter of 1998 to the third quarter of 2006. Financial data are gathered from the first quarter of 1998 to the third quarter of 2006, although the number of airline companies that report information in each quarter varies. ${ }^{2}$

Table 1 provides an overview of the descriptive statistics of the customer service variables for each airline during the time period. About one-third of these airlines (six) provided detailed information over the whole period of investigation while the others reported partial statistics.

Table 1: Descriptive Statistics for the Different Customer Service Measures per Airline

\begin{tabular}{|c|c|c|c|c|c|}
\hline Airline & $\begin{array}{l}\text { \# of } \\
\text { Obs. }\end{array}$ & $\begin{array}{c}\text { On-Time } \\
\text { Performance } \\
(\%)\end{array}$ & $\begin{array}{c}\text { Mishandled } \\
\text { Bags } \\
\text { (per 1,000 } \\
\text { passengers) }\end{array}$ & $\begin{array}{c}\text { Ticket } \\
\text { Over-Sales } \\
\text { (per 10,000 } \\
\text { passengers) }\end{array}$ & $\begin{array}{c}\text { Complaints } \\
\text { (per } 100,000 \\
\text { passenger) }\end{array}$ \\
\hline ATA Airlines & 10 & 81.320 & 3.771 & 2.142 & 0.737 \\
\hline AirTran Airways & 15 & 75.471 & 3.359 & 0.611 & 0.860 \\
\hline Alaska Airlines & 34 & 73.442 & 4.168 & 1.223 & 1.016 \\
\hline Aloha Airlines & 1 & 82.467 & 5.487 & 0.080 & 0.109 \\
\hline America West Airlines & 31 & 75.461 & 4.221 & 0.779 & 2.717 \\
\hline American Airline & 34 & 77.709 & 4.958 & 0.504 & 1.789 \\
\hline American Eagle Airlines & 23 & 75.536 & 9.509 & 0.716 & 0.834 \\
\hline Atlantic Southeast Airlines & 15 & 72.589 & 15.236 & 4.079 & 0.586 \\
\hline Comair Inc. & 11 & 78.000 & 10.378 & 1.867 & 1.147 \\
\hline Continental Air & 34 & 79.129 & 4.066 & 1.264 & 1.552 \\
\hline Delta Air Lines & 34 & 78.399 & 4.715 & 1.110 & 1.458 \\
\hline Frontier Airlines & 6 & 81.244 & 4.990 & 0.353 & 0.510 \\
\hline Hawaiian Airlines & 12 & 94.214 & 3.202 & 0.180 & 0.553 \\
\hline Independence Airlines & 4 & 77.338 & 4.456 & 0.008 & 1.417 \\
\hline jetBlue Airways & 15 & 78.138 & 3.748 & 0.018 & 0.295 \\
\hline Mesa Airlines & 3 & 73.700 & 10.326 & 1.740 & 1.537 \\
\hline Northwest Airlines & 34 & 78.468 & 4.716 & 0.603 & 1.724 \\
\hline Skywest Airlines & 11 & 81.294 & 9.992 & 0.525 & 0.559 \\
\hline Southwest Airlines & 34 & 81.065 & 4.355 & 1.242 & 0.302 \\
\hline US Airways & 30 & 77.538 & 5.060 & 0.452 & 1.729 \\
\hline US Airways Merged $^{12}$ & 4 & 78.350 & 7.821 & 0.933 & 1.487 \\
\hline United Air Lines & 34 & 76.186 & 5.392 & 0.726 & 2.056 \\
\hline Total \# of Observations & 429 & & & & \\
\hline Grand Mean & & 77.888 & 5.484 & 0.962 & 1.329 \\
\hline
\end{tabular}


In terms of on-time performance, the data measure the number of flights that arrived within 15 minutes of the originally scheduled arrival time. Overall on-time performance across all airlines averaged almost 78\% (77.89\%) of all flights during the 1998-2006 time frame. Hawaiian Airlines performed best over the observed period with an average on-time performance of more than $94 \%$. Atlantic Southeast Airlines, on the other hand, performed worst: on average more than $27 \%$ of its flights arrived late.

The second variable in Table 1 relates to the number of reported mishandled bags per 1,000 passengers. On average, across all airlines, about 5.5 bags were reported lost or damaged or arrived late for every 1,000 passengers. Again, Hawaiian Airlines performed best over the reported period of time. Hawaiian's average number of mishandled bags was 3.2 per 1,000 passengers. On the other extreme, Atlantic Southeast Airlines again performed worst: on average, it mishandled 15.2 bags per 1,000 passengers.

Ticket over-sales refers to the number of passengers that involuntarily could not board the flight on which they had booked a ticket due to over-booking by the airline. On average, one passenger per every 10,000 was refused boarding on a flight. Independence Airlines performed best in this category. Only six in every 10 million passengers were denied boarding. ${ }^{3}$ On the other extreme, Atlantic Southeast Airlines denied boarding to every 2,500 $0^{\text {th }}$ passenger - almost four times the average for the period under study.

Complaints refer to the number of officially filed complaints (to the Department of Transportation) per 100,000 passengers. On average, the airlines received more than 1.3 complaints per 100,000 passengers. The best performer in this category was Aloha Airlines. Overall, this airline only received about 0.10 complaints per 100,000 customers. ${ }^{4}$ On the other extreme, America West Airlines received 2.72 complaints per 100,000 passengers, more than twice the industry average.

\section{Model Specification}

Although complaints were originally included as a measure of customer service, Dresner and Xu (1995) found that the number of complaints is heavily determined by on-time performance, the number of ticket over-sales, and the number of mishandled bags. Hence, in the further analysis, we focus on customer service as measured by on-time performance, ticket over-sales, and mishandled baggage, although we provide an estimation of customer complaints in the appendix.

Seemingly unrelated regressions (SUR) is used to estimate the three customer service measures simultaneously since our measures of customer service are likely to have highly correlated error terms. ${ }^{5}$ The following equations are estimated simultaneously:

(1) Ontime $=\alpha_{0}+\alpha_{1}$ LagZscore $+\alpha_{2}$ Loadfactor $+\alpha_{3}$ Coupons $+\alpha_{4}$ Passenger $+\sum \gamma_{\mathrm{i}}$ Time $+\sum \eta_{\mathrm{j}}$ Airline $+\varepsilon$

(2) Bags $=\beta_{0}+\beta_{1}$ LagZscore $+\beta_{2}$ Loadfactor $+\beta_{3}$ Coupons $+\beta_{4}$ Passenger $+\sum \gamma_{\mathrm{i}}$ Time $+\sum \eta_{\mathrm{j}}$ Airline $+\varepsilon$

(3) Bumped $=\chi_{0}+\chi_{1}$ LagZscore $+\chi_{2}$ Loadfactor $+\chi_{3}$ Coupons $+\chi_{4}$ Passenger $+\sum \gamma_{\mathrm{i}}$ Time $+\sum \eta_{\mathrm{j}}$ Airline $+\varepsilon$

\section{Measures}

Dependent Variables - The three customer service measures are dependent variables as described above: On-time performance ('ontime'), mishandled baggage ('bags'), and ticket over-sales ('bumped'). While the distribution of ontime is reasonably normal, the distributions of bags and bumped are highly skewed. The natural logarithms of these variables are, therefore, used in 
the analysis in order to achieve more normal distributions. Table 2 provides an overview of the descriptive statistics for all dependent and independent variables.

Table 2: Descriptive Statistics

\begin{tabular}{|c|c|c|c|c|c|}
\hline & \# of Obs. & Mean & Std. Dev. & Min & Max \\
\hline Z-Score (inverse) $)^{13}$ & 428 & 0.605 & 6.25 & -3.77 & 85.82 \\
\hline On-Time Performance (in \%) & 429 & 77.889 & 6.07 & 52.07 & 96.70 \\
\hline $\begin{array}{l}\text { Mishandled Baggage (per 1,000 } \\
\text { passengers) }\end{array}$ & 429 & 5.484 & 3.07 & 2.17 & 21.85 \\
\hline $\begin{array}{l}\text { Ticket Over-Sales (per 10,000 } \\
\text { passengers) }\end{array}$ & 429 & 0.962 & 1.09 & 0.00 & 11.79 \\
\hline Complaints (per 100,000 passengers) & 429 & 1.329 & 1.26 & 0.11 & 9.06 \\
\hline Load Factor & 429 & 73.436 & 6.20 & 52.95 & 91.50 \\
\hline Low Cost Carrier $(1=\mathrm{LCC})$ & 429 & 0.268 & 0.44 & 0.00 & 1.00 \\
\hline Coupons (per itinerary) & 429 & 3.493 & 0.30 & 1.88 & 4.21 \\
\hline Passengers (in 100,000) & 429 & 100.400 & 77.48 & 0.37 & 273.53 \\
\hline
\end{tabular}

Independent Variables - The main independent variable for this study is financial distress. Altman's Z-Score is used to measure the financial heath of an airline. Following Hofer et al. (2005), the revised Z-Score ('Zscore') (Altman 2002) for service companies is employed in this study, consisting of a weighted combination of the following financial ratios: $X 1$, working capital/total assets, $X 2$, retained earnings/total assets, $X 3$, earnings before interest and taxes/total assets, and $X 4$, book value of equity/total liabilities. ${ }^{6}$ The inverse of this scale is used in order to measure distress rather than financial health of a company. High (positive) scores indicate financial distress in a company while low (or negative) scores are a sign of financial health. The Z-Score variable is lagged ('LagZscore') by one quarter so that financial distress and customer service levels are not simultaneously determined. ${ }^{7}$ Table 2 shows that the mean for the main independent variable is positive (0.605), ranging from a maximum of 85.82 to a minimum of -3.77 . According to Altman (2000), the cut-off value to determine whether the firm is in financial distress or not is -2.6 for nonmanufacturing firms. This results in only 12 'healthy' observations of the total 428 observations $(\sim 2.8 \%)$. These data indicate the severity of the financial difficulties the U.S. airline industry experienced during the 1998 to 2006 time period.

Control Variables - In the analysis, a number of other factors are controlled that may influence customer service levels. All control measures in this study are company-specific. Although the main independent variable is lagged, current period observations for the control variables are used as they are likely to have a more immediate effect on the dependent variable.

First, we control for company size; i.e., total number of passengers ('passengers') per quarter carried by an airline. ${ }^{8}$ An airline's size is likely to affect the complexity of its operations. Larger airlines may have more complex hub structures, thus increasing the likelihood of lost bags due to stopovers and delayed flights. On the other hand, larger airlines are also more likely to have the means to implement sophisticated forecasting models and operations management tools that should result in lower numbers of bumped customers and fewer delayed flights. So the net impact of airline size on the customer service variables cannot be predicted a priori.

Low cost carrier ('LCC') may also be a proxy for the complexity of airline operations as low cost carriers generally do not operate with a complex hub structure and are likely, therefore, to have fewer misplaced bags and better on-time performance. This variable is coded as binary. Low-cost carriers include: Airtran Airways, American Trans Air, America West Airlines, Frontier Airlines, jetBlue Airways, and Southwest Airlines. ${ }^{9}$ 
The average number of legs per trip is included ('coupons') and is measured as the average number of legs per itinerary by an operating airline in a quarter. Since customers usually buy roundtrip tickets, the mean for coupons should be at least 2. The mean for our sample is 3.49 (see Table 2). It can be assumed that this variable will have a significant effect on the number of mishandled bags (i.e., more transfers, more misplaced bags).

Finally, we include load factor ('load factor') as a control variable. Load factor refers to the percentage of seats filled per plane (ranging from 0 to 100) and is measured on a quarterly basis. Load factor may influence delayed flights and the number of bumped customers.

Table 3 shows the correlations between the variables. Although several of the correlations are statistically significant at the $1 \%$ level, one correlation in particular stands out: coupons and low-cost carrier (LCC) are highly negatively correlated (-0.702) supporting the contention that lowcost carriers connect fewer passengers at their hubs. Given this high correlation, both variables are not used in the same model to avoid multicollinearity. Number of coupons is used rather than the low cost carrier variable, as it is a continuous variable, and, hence, provides a richer source of information.

Table 3: Correlation Table

\begin{tabular}{|c|c|c|c|c|c|c|c|c|}
\hline & $\begin{array}{l}\text { Lagged } \\
\text { Z-Score }\end{array}$ & $\begin{array}{c}\text { On-Time } \\
\text { Performance }\end{array}$ & $\begin{array}{c}\text { Mishandled } \\
\text { Baggage }\end{array}$ & $\begin{array}{c}\text { Ticket Over- } \\
\text { Sales }\end{array}$ & Complaints & Load Factor & $\begin{array}{c}\text { Low Cost } \\
\text { Carrier }\end{array}$ & Coupons \\
\hline $\begin{array}{l}\text { On-Time } \\
\text { Performance }\end{array}$ & $\begin{array}{l}0126^{* * *} \\
0009\end{array}$ & 1 & & & & & & \\
\hline $\begin{array}{l}\text { Mishandled } \\
\text { Baggage }\end{array}$ & $\begin{array}{l}-0055 \\
0260\end{array}$ & $\begin{array}{l}-0318^{* * * *} \\
0000\end{array}$ & 1 & & & & & \\
\hline $\begin{array}{l}\text { Ticket Over- } \\
\text { Sales }\end{array}$ & $\begin{array}{l}0084^{*} \\
0083\end{array}$ & $\begin{array}{l}-0191^{* * *} \\
0000\end{array}$ & $\begin{array}{l}0385 \\
0000\end{array}$ & 1 & & & & \\
\hline Complaints & $\begin{array}{l}-0040 \\
0409\end{array}$ & $\begin{array}{l}-0454^{* * * *} \\
0000\end{array}$ & $\begin{array}{l}-0012 \\
0804\end{array}$ & $\begin{array}{l}-0055 \\
0253\end{array}$ & 1 & & & \\
\hline Load Factor & $\begin{array}{l}0046 \\
0339\end{array}$ & $\begin{array}{l}0236^{* * *} \\
0000\end{array}$ & $\begin{array}{l}-0152^{* * *} \\
0002\end{array}$ & $\begin{array}{l}-0163 * * * \\
0001\end{array}$ & $\begin{array}{l}-0178^{* * *} \\
0000\end{array}$ & 1 & & \\
\hline $\begin{array}{l}\text { Low Cost } \\
\text { Carrier }\end{array}$ & $\begin{array}{l}0042 \\
0387\end{array}$ & $\begin{array}{l}0046 \\
0347\end{array}$ & $\begin{array}{l}-0274 * * * \\
0000\end{array}$ & $\begin{array}{l}-0054 \\
0261\end{array}$ & $\begin{array}{l}-0104^{* *} \\
0032\end{array}$ & $\begin{array}{l}-0005 \\
0918\end{array}$ & 1 & \\
\hline Coupons & $\begin{array}{l}-0083^{*} \\
0088\end{array}$ & $\begin{array}{l}-0017 \\
0722\end{array}$ & $\begin{array}{l}0287 * * * \\
0000\end{array}$ & $\begin{array}{l}0049 \\
0308\end{array}$ & $\begin{array}{l}0268^{* * * *} \\
0000\end{array}$ & $\begin{array}{l}-0119^{* *} \\
0014\end{array}$ & $\begin{array}{l}-0702^{* * *} \\
0000\end{array}$ & 1 \\
\hline Passenger & $\begin{array}{l}-0089^{*} \\
0067\end{array}$ & $\begin{array}{l}0029 \\
0546\end{array}$ & $\begin{array}{l}-0283^{* * *} \\
0000\end{array}$ & $\begin{array}{l}-0128^{* *} \\
0008\end{array}$ & $\begin{array}{l}0171^{* * * *} \\
0000\end{array}$ & $\begin{array}{l}-0027 \\
0574\end{array}$ & $\begin{array}{l}-0143^{* * *} \\
0003\end{array}$ & $\begin{array}{l}0115^{* *} \\
0017\end{array}$ \\
\hline
\end{tabular}

*sig. at the $10 \%$ level, $* *$ sig. at the $5 \%$ level, $* * *$ sig. at the $1 \%$ level.

\section{RESULTS}

\section{SUR Model}

Table 4 displays the regression results for the SUR model. Due to heteroskedasticity in the data set, we report only robust results. ${ }^{10}$ The results indicate that the lagged Z-Score has a highly significant effect on on-time performance and the number of mishandled bags, but no significant effect on the number of ticket over-sales (bumped customers). Specifically, these results imply that as an airline's financial distress increases, on-time performance increases, while the number of mishandled bags decreases. The findings lend support to the argument that financially distressed companies are more likely to have better on-time and baggage handling performance in order to turn their company around (i.e. attract customers). ${ }^{11}$ 
Table 4: SUR Results (controlling for Heteroskedasticity)

\begin{tabular}{|c|c|c|c|}
\hline & $\begin{array}{c}\text { On-Time } \\
\text { Performance }\end{array}$ & $\begin{array}{c}\text { Mishandled } \\
\text { Baggage (log) }\end{array}$ & $\begin{array}{c}\text { Ticket Over- } \\
\text { Sales (log) }\end{array}$ \\
\hline \multirow[t]{2}{*}{ Lagged Z-Score } & 0.146 & -0.008 & 0.117 \\
\hline & $(3.16)^{* * *}$ & $(2.62)^{* * *}$ & $(1.53)$ \\
\hline \multirow[t]{2}{*}{ Load Factor } & 0.360 & -0.034 & -0.375 \\
\hline & $(6.71)^{* * *}$ & $(9.88)^{* * *}$ & $(4.19)^{* * *}$ \\
\hline \multirow[t]{2}{*}{ Passenger } & 0.007 & -0.001 & 0.023 \\
\hline & $(2.04)^{* *}$ & $(3.83)^{* * *}$ & $(4.07)^{* * *}$ \\
\hline \multirow[t]{2}{*}{ Coupons } & -0.204 & 0.584 & 9.536 \\
\hline & $(0.25)$ & $(10.95)^{* * *}$ & $(6.92)^{* *}$ \\
\hline \multirow[t]{2}{*}{ Quarter 1} & -1.062 & -0.031 & -0.413 \\
\hline & $(1.44)$ & $(0.65)$ & $(0.34)$ \\
\hline \multirow[t]{2}{*}{ Quarter 2} & -1.257 & 0.032 & 2.243 \\
\hline & $(1.72)$ & $(0.68)$ & $(1.84)^{*}$ \\
\hline \multirow[t]{2}{*}{ Quarter 3} & -2.040 & 0.087 & 0.331 \\
\hline & $(2.81)^{* * *}$ & $(1.85)^{*}$ & $(0.27)$ \\
\hline \multirow[t]{2}{*}{1998} & 1.836 & -0.609 & -5.471 \\
\hline & (1.38) & $(7.08)^{* * *}$ & $(2.46)^{* *}$ \\
\hline \multirow[t]{2}{*}{1999} & 1.123 & -0.649 & -5.861 \\
\hline & $(0.90)$ & $(8.09)^{* * *}$ & $(2.83)^{* * *}$ \\
\hline \multirow[t]{2}{*}{2000} & -2.574 & -0.538 & -4.526 \\
\hline & $(2.13)^{* *}$ & $(6.89)^{* * *}$ & $(2.24)^{* *}$ \\
\hline \multirow[t]{2}{*}{2001} & 4.476 & -0.836 & -5.713 \\
\hline & $(3.63)^{* * *}$ & $(10.49)^{* * *}$ & $(2.78)^{* * *}$ \\
\hline \multirow[t]{2}{*}{2002} & 8.100 & -0.917 & -6.789 \\
\hline & $(6.76)^{* * *}$ & $(11.87)^{* * *}$ & $(3.40)^{* * *}$ \\
\hline \multirow[t]{2}{*}{2003} & 6.733 & -0.726 & -5.781 \\
\hline & $(6.49)^{* * *}$ & $(10.84)^{* * *}$ & $(3.34)^{* * *}$ \\
\hline \multirow[t]{2}{*}{2004} & 4.007 & -0.513 & -4.187 \\
\hline & $(4.12)^{* * *}$ & $(8.18)^{* * *}$ & $(2.58)^{* * *}$ \\
\hline \multirow[t]{2}{*}{2005} & 1.490 & -0.211 & -4.628 \\
\hline & $(1.59)$ & $(3.49)^{* * *}$ & $(2.95)^{* * *}$ \\
\hline \multirow[t]{2}{*}{ Constant } & 49.594 & 2.642 & -6.329 \\
\hline & $(9.70)^{* * *}$ & $(8.01)^{* * *}$ & $(0.74)$ \\
\hline Observations & 428 & 428 & 428 \\
\hline LR chi ${ }^{2}(45)$ & 477.99 & & \\
\hline Prob $>$ chi $^{2}$ & 0.000 & & \\
\hline Log-likelihood & -2924.21 & & \\
\hline
\end{tabular}

Absolute value of $\mathrm{z}$ statistics in parentheses. * significant at $10 \% ; * *$ significant at $5 \% ; * * *$ significant at $1 \%$. Quarter dummy in reference to Quarter 4 (October to December); Yearly dummy in reference to 2006. 
In all three of the models load factor is highly significant. As load factor increases, on-time performance increases, while the number of mishandled bags and number of over-sold tickets decrease. These findings indicate that airlines that achieve higher fill rates generally have better organizational and operational skills resulting in better customer service.

The size variable 'passengers' is also statistically significant in all three models. Larger airlines have higher on-time performance and lower numbers of mishandled bags but higher ticket oversales. These findings are contradictory: although larger airlines seem to be better able to manage on-time arrivals and handle baggage, they also appear to manage the number of over-bookings less well than smaller airlines. This indicates that operational efficiency might increase with size, but smaller airlines seem to have fewer bumped customers.

The control variable 'coupons' is significant in the model of mishandled bags ( $1 \%$ level) and for the ticket over-sales model (5\% level). However, the effect is insignificant in the on-time performance model. As expected, an increase in the number of legs in an itinerary results in an increase in the number of mishandled bags. Fewer legs, and hence the option to have more direct control over actual passengers on a particular flight, reduces the number of bumped customers.

\section{Application of Results}

Following is an overview of how the results may be interpreted. Using the seemingly unrelated regression results, we predict on-time performance and mishandled bags assuming that all independent variables are consistent across time and airlines. From Table 5, it can be observed that the average lagged Z-Score (across all airlines and time periods) equals 0.45 . Using the estimated coefficients from the model, and assuming all other variables are at their means, this translates into an estimated on-time performance of $77.5 \%$ and in five mishandled bags per 1,000 passengers - for an airline in any given quarter.

An airline that has a Z-Score one standard deviation below the mean (i.e. performs financially better than industry average) would, on average, achieve an on-time performance of only $76.7 \%$ (again, using the estimated coefficients from the regression and assuming other variables are at their means), while an airline that performs one standard deviation above the mean Z-score (i.e. performs financially worse than industry average) has a better-than-average on-time performance of $78.3 \%$. Similarly, an airline with a Z-Score one standard deviation below the industry average (more financially solvent than the mean carrier) would lose 5.21 bags (per 1,000 passengers). An airline that is financially more distressed, with a Z-Score of one standard deviation above the industry average, is predicted to lose only 4.76 bags (per 1,000 passengers).

The second part of Table 5 displays the estimated on-time performance of selected airlines and the number of mishandled bags assuming that the other independent variables, such as load factor and number of coupons per itinerary, are at the mean for all airlines. ATA was chosen as an example because it had the worst financial performance. American Eagle performed at about the industry average, while Skywest was the financially healthiest company in this data set. The results indicate that the spread between best and worst performer in the airline industry - keeping all other factors constant - accounts for a difference in on-time performance of about 3.3 percentage points $(77.1 \%$ to $80.4 \%$ ), and about 0.84 mishandled bags (per 1,000 passenger). 
Table 5: Impact of Financial Distress on On-Time Performance and Mishandled Bags

\begin{tabular}{|c|c|c|c|}
\hline & Lagged Z-Score & $\begin{array}{c}\text { Estimated On-Time } \\
\text { Performance } \\
(\text { in } \%)\end{array}$ & $\begin{array}{c}\text { Estimated \# of } \\
\text { Mishandled Bags } \\
\text { (per 1,000 passenger) }\end{array}$ \\
\hline Average (mean) & 0.45 & 77.50 & 5.00 \\
\hline $\begin{array}{l}\text { - } 1 \text { Standard } \\
\text { Deviation }\end{array}$ & -4.95 & 76.72 & 5.21 \\
\hline $\begin{array}{l}+1 \text { Standard } \\
\text { Deviation }\end{array}$ & 5.86 & 78.29 & 4.76 \\
\hline \multicolumn{4}{|l|}{ Example Airlines } \\
\hline ATA Airlines & 19.33 & 80.39 & 4.26 \\
\hline American Eagle & 0.57 & 77.63 & 4.95 \\
\hline Skywest Airlines & -3.18 & 77.11 & 5.10 \\
\hline
\end{tabular}

\section{LIMITATIONS, FUTURE RESEARCH AND CONCLUSIONS}

This paper examines the relationship between financial distress and customer service levels using data from the airline industry. The results indicate, perhaps surprisingly, that financial distress contributes to better customer service measures in terms of higher on-time performance and fewer numbers of mishandled bags. However, significant results for financial distress impacting ticket over-sales are not found. These results, overall, are very robust.

A limitation of this paper is, as previous studies have shown (Ittner and Larcker 1998, Hofer et al. 2005), that there may also exist an effect of customer service measures on financial performance or distress. Hence, it can be argued that a simultaneity bias is present. Although a lagged variable for financial distress was used to address this issue, future research could investigate the simultaneous relationship between financial distress and customer service.

A possible explanation for the positive association between financial distress and customer service (i.e., on-time performance and number of mishandled bags) is that financially stable organizations may be unlikely to change their winning strategies. A company in financial distress, on the other hand, needs to change its organization in order to turn around. One option to increase revenues is to attract new customers and retain existing ones. Hence, a good reputation creates opportunities for future revenues.

It is important to note that both on-time performance and number of mishandled bags are customer service measures that an airline can address (e.g., by increasing scheduled flight times). As well, with additional training, ground personnel can be schooled in order to provide more efficient handling of bags, hence resulting in fewer lost bags. Therefore, an important result from this analysis is that airlines have the means within their managerial purview to increase customer service levels, should they find that doing so in their best interest. 


\section{APPENDIX A}

\section{Appendix Table 1: OLS Results}

\begin{tabular}{|c|c|c|c|c|}
\hline & $\begin{array}{c}\text { On-time } \\
\text { Performance }{ }^{\#} \\
\ldots \ldots \ldots \ldots \ldots \ldots \ldots\end{array}$ & $\begin{array}{c}\text { Mishandled Bags } \\
(\log )^{\#}\end{array}$ & $\begin{array}{c}\text { Ticket Over-Sales } \\
\text { (log) }\end{array}$ & Complaints (log) \\
\hline \multirow[t]{2}{*}{ Lagged Z-Score } & $\begin{array}{c}0.146 \\
\ldots \ldots \ldots\end{array}$ & -0.008 & 0.117 & 0.020 \\
\hline & $(5.61)^{* * *}$ & $\begin{array}{l}(4.73)^{* * *} \\
(\ldots \ldots \ldots\end{array}$ & $(1.50)$ & $(3.55)^{* * *}$ \\
\hline \multirow[t]{2}{*}{ Load Factor } & 0.360 & $\begin{array}{l}-0.034 \\
\ldots \ldots \ldots\end{array}$ & $\begin{array}{l}-0.375 \\
\ldots \ldots \ldots\end{array}$ & $\begin{array}{l}-0.025 \\
\ldots \ldots \ldots\end{array}$ \\
\hline & $(4.67)^{* * *}$ & $(7.56)^{* * *}$ & $(4.11)^{* * *}$ & $(4.39)^{* * *}$ \\
\hline \multirow[t]{2}{*}{ Passenger } & 0.007 & -0.001 & 0.023 & -0.001 \\
\hline & $(1.97)^{* *}$ & $(4.02)^{* * *}$ & $(4.00)^{* * *}$ & $(1.72)^{*}$ \\
\hline \multirow[t]{2}{*}{ Coupons } & -0.204 & 0.584 & $\begin{array}{l}9.536 \\
\ldots . \ldots . .\end{array}$ & 1.281 \\
\hline & $(0.22)$ & $(7.94)^{* * *}$ & $(6.79)^{* * *}$ & $(12.56)^{* * *}$ \\
\hline \multirow[t]{2}{*}{ On-Time Performance } & & & & -0.054 \\
\hline & & & & $(11.77)^{* * *}$ \\
\hline \multirow[t]{2}{*}{ Mishandled Baggage } & & & & -0.051 \\
\hline & & & & $(3.96)^{* * *}$ \\
\hline \multirow[t]{2}{*}{ 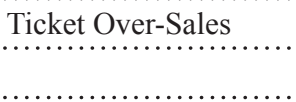 } & & & & $\begin{array}{l}-0.021 \\
\ldots \ldots \ldots\end{array}$ \\
\hline & & & & $(0.92)$ \\
\hline \multirow[t]{2}{*}{ Constant } & 49.594 & 2.642 & -6.329 & $-2.305^{* * *}$ \\
\hline & $(7.57)^{* * *}$ & $(7.03)^{* * *}$ & $(0.73)$ & $(3.91)$ \\
\hline $\begin{array}{l}\text { Observations }(\mathrm{N}) \\
\ldots \ldots \ldots \ldots \ldots \ldots \ldots\end{array}$ & $\begin{array}{l}428 \\
\ldots \ldots\end{array}$ & 428 & $\begin{array}{l}428 \\
\ldots \ldots\end{array}$ & $\begin{array}{l}428 \\
\ldots \ldots\end{array}$ \\
\hline R-squared & 0.32 & 0.46 & 0.19 & 0.69 \\
\hline
\end{tabular}

$*$ significant at $10 \% ; * *$ significant at $5 \% ; * * *$ significant at $1 \%$

Absolute value of t-statistics in parentheses

\# Robust Analysis: Robust t-statistics in parentheses

Yearly and quarterly dummy variables not reported.

\section{Endnotes}

1. SERVQUAL is a service quality framework developed to measure the gap between perceived and expected service quality in organizations. It was originally developed by Parasuraman, Zeithaml, and Berry (1988).

2. All airlines that earn at least $1 \%$ of total domestic scheduled-service passenger revenues are required to provide information about their performance. Additionally, other carriers may voluntarily disclose this information.

3. However, it should be kept in mind that the dataset only reports four observations for this airline. The results might reflect the fact that this start-up airline operated at a lower load factor than most of its competitors.

4. This result was based on only one observation.

5. OLS regression results are reported in Appendix A.

6. $\mathrm{Z}=6.56 * \mathrm{X} 1+3.26 * \mathrm{X} 2+6.72 * \mathrm{X} 3+1.05 * \mathrm{X} 4$ 
7. Other estimations without the Z-Score lagged provide similar results to our model.

8. This variable is re-scaled by dividing passengers by 100,000 in order to provide coefficients in a reasonable range.

9. The same list as Hofer et al. (2005): This study investigated the error terms of actual operating expenses per average seat mile (ASM) regressed on average trip length. The authors assumed that the error terms reflect "all differences in operating costs that cannot be attributed to differences in average stage length, and can be viewed as indicators of operating efficiency" (Hofer et al. 2005, p.331). Using this method, the authors identified 12 carriers as low-cost carriers, seven of which are also present in the data set of this study.

10. Stata SE 10 provides a slight variation of the SUR model in the form of a log-likelihood model (mysureg) that controls for heteroskasticity. The results between the two models do not change significantly.

11. The results are very similar to those found in the OLS regression.

12. US Airways is mentioned twice (US Airways and US Airways Merged) due to the merger of America West Airlines and US Airways in the third quarter of 2005. America West bought US Airways but decided to continue operating under the name of US Airways. In order to avoid misrepresentations in the data, observations after the merger are treated as an independent company.

13. The DOT did not report retained earnings for United Airlines in quarter 3 of 2005; we were unable to compute the Z-Score for this quarter for United Airlines resulting in one less observation.

\section{References}

Air Travel Consumer Reports. http://airconsumer.ost.dot.gov/reports/index htm; March 6, 2007.

Airline Quarterly Financial Reviews. http://ostpxweb.dot.gov/aviation/X-50\%20Role_files/ airlinefinancialreview htm; March 20, 2007.

Altman, E.I. "Financial Ratios, Discriminant Analysis and the Prediction of Corporate Bankruptcy." Journal of Finance 23(4), (1968): 589-609.

Altman, E.I. Predicting Financial Distress of Companies: Revisiting The Z-Score and Zeta Models. New York: Stern, New York University (2000): 1-54.

Altman, E.I. Bankruptcy, Credit Risk, and High Yield Junk Bonds. Blackwell Publishers, Malden, Massachusetts, 2002.

American Bankruptcy Institute. “US Bankruptcy Filings 1980-2005.” www.abiworld.org; December $15,2006$.

Anonymous. "Company News; US Airways Will Lay Off 2,500 Employees.” The New York Times. November 27, 2002, New York.

Anonymous. "US Airways to Lay Off Mechanics in Phila." Philadephia Business Journal. February 4, 2005, Philadelphia. 
Behn, B.K. and R.A.J. Riley. "Using Nonfinancial Information to Predict Financial Performance: The Case of the U.S. Airline Industry." Journal of Accounting, Auditing \& Finance 14(1), (1999): 29-56.

Belden, T. and C. R. McCoy. "Baggage Bungling: US Airways Concedes its Philadelphia Handling has been a Mess. Here's Why." Philly.com, October 8, 2006.

Borenstein, S. and N.L. Rose. "The Impact of Bankruptcy on Airline Service Levels." Paper presented at the American Economics Association, 2003.

Bureau of Transportation Statistics (BTS)/U.S. Department of Transportation. http://www.transtats. bts.gov/DataIndex.asp; March 10, 2007.

CERT, Group. http://www.cert.co.uk/about html; May 2, 2007.

Chung, C.C. and M. Szenberg. "The Effects of Deregulation on the U.S. Airline Industry." Journal of Applied Business Research 12(3), (1996): 133-140.

Cunningham, L.F. and M. Lee. "Cross-Cultural Perspectives of Service Quality and Risk in Air Transportation." Journal of Air Transportation 7(1), (2002): 3-26.

Cunningham, L.F., E.Y. Clifford, and M. Lee. "Perceptions of Airline Service Quality: Pre and Post 9/11.” Public Works Management \& Policy 9 (1), (2004): 10-25.

Dick, A.S. and K. Basu. "Customer Loyalty: Towards an Integrated Conceptual Framework." Journal of the Academy of Marketing Science 22(2), (1994): 99-113.

Dresner, M. and K. Xu. "Customer Service, Customer Satisfaction, and Corporate Performance in the Service Sector.” Journal of Business Logistics 16(1), (1995): 23-40.

Ellinger, A.E., P.J. Daugherty, and Q.J. Plair. "Customer Satisfaction and Loyalty in Supply Chains: The Role of Communication." Transportation Research E: Logistics and Transportation Review 35(2), (1999): 121-134.

Evans, J. and T. Koch. "Surviving Chapter 11: Why Small Firms Prefer Supplier Financing.” Journal of Economics \& Finance 31(2), (2007): 186-206.

Gourdin, K.N. and T.J. Kloppenborg. "Identifying Service Gaps in Commercial Air Travel: The First Step Toward Quality Improvement.” Transportation Journal 31(1), (1991): 22-30.

Grinyer, P. and P. McKiernan. "Generating Major Change in Stagnating Companies." Strategic Management Journal 11(4), (1990): 131-146.

Gritta, R.D., G. Chow, and E. Freed. "Business, Financial, and Total Risk in Air Transport: A Comparison to Other Industry Groups Prior to September 11, 2001." Transportation Quarterly 57(4), (2003): 149-156.

Gritta, R.D., B. Adrangi, S. Davalos, and D. Bright. "A Review of the History of Air Carrier Bankruptcy Forecasting and the Application of Various Models to the U.S. Airline Industry: 19802005.” International Economic History Congress, Helsinki, 2006.

Heskett, J.L., T.O. Jones, G.W. Loveman, W.E. Sasser Jr., and L.A. Schlesinger. "Putting the ServiceProfit Chain to Work." Harvard Business Review, March-April 1994: 164-174. 
Hofer, C., M. Dresner, and R. Windle. "Financial Distress and US Airline Fares." Journal of Transport Economics and Policy 39(3), (2005): 323-340.

Hofer, C.W. “Turnaround Strategies.” Journal of Business Strategy 1(1), (1980): 19-31.

Institute, A.B. “Weekly Bankruptcy Statistics.” In A.B. Institute (Ed.), 2006.

Ittner, C.D. and D.F. Larcker. “Are Nonfinancial Measures Leading Indicators of Financial Performance? An Analysis of Customer Satisfaction." Journal of Accounting Research 36, (1998): $1-35$.

Lainas, M. "Creating a New Culture: The CERT Challenge." Supply Chain Management: An International Journal 4(5), (1999): 226-230.

Lambert, D.M. and J.U. Sterling. "Establishing Customer Service Strategies Within the Marketing Mix.” Journal of Business Logistics 8(1), (1987): 1-37.

Lovelock, C. Product Plus: How Product + Service = Competitive Advantage. McGraw-Hill, Inc., New York, New York, 1994.

Mazzeo, M.J. "Competition and Service Quality in the U.S. Airline Industry.” Review of Industrial Organization 22(4), (2003): 275-296.

Parasuraman, A., V.A. Zeithaml, and L.L. Berry. "SERVQUAL: A Multiple-Item Scale for Measuring Consumer Perceptions of Service Quality." Journal of Retailing 64(1), (1988):12-40.

Parasuraman, A. "Consumer Service in Business-to-Business Markets: An Agenda for Research." Journal of Business \& Industrial Marketing 13 (4/5), (1998): 309-321.

Pearce, J.A.I. and K. Robbins. "Toward Improved Theory and Research on Business Turnaround." Journal of Management 19(3), (1993): 613-636.

Pearce, J.A.I. and D. Keith Robbins. "Retrenchment Remains the Foundation of Business Turnaround." Strategic Management Journal 15(5), (1994): 407.

Robbins, D.K. and J.A.I. Pearce. "Turnaround: Retrenchment and Recovery.” Strategic Management Journal 13(4), (1992): 287-309.

Routledge, J. and D. Gadenne. "Financial Distress, Reorganization and Corporate Performance." Accounting and Finance 40(3), (2000): 233-260.

Schlossberg, D. "US Airways Still Sorting Out Lost Bags.” http://www.consumeraffairs.com/ news04/2007/02/travel_usair html; February 22, 2007.

Smith, M. and C. Graves. "Corporate Turnaround and Financial Distress." Managerial Auditing Journal 20(3), (2005): 304-320.

Suzuki, Y. "The Relationship Between On-time Performance and Airline Market Share: A New Approach." Transportation Research E: Logistics and Transportation Review 36(2), (2000): 139154.

Wiles, M.A. "The Effect of Customer Service on Retailers' Shareholder Wealth: The Role of Availability and Reputation Cues.” Journal of Retailing 83(1), (2007): 19-31. 
Dina Ribbink is a Ph.D. candidate in logistics, transportation and supply chain management at the R.H. Smith School of Business at the University of Maryland. Her dissertation focuses on the impact of culture on buyer-supplier relationships. Ribbink also studies transportation-related issues with special focus on intermodal transportation and the airline industry. Before joining the Ph.D. program, Ribbink taught various classes in the field of transportation and supply chain management at the Maastricht University, the Netherlands, and worked as a research assistant at the University of Liege, Belgium.

Christian Hofer is assistant professor of transportation and logistics in the Sam M. Walton College of Business, University of Arkansas. He joined the faculty of the Department of Marketing and Logistics in the fall of 2007 after completing his Ph.D. in supply chain management, logistics, and transportation at the University of Maryland. Hofer received his BA with honors in multinational studies in general and international business from the European School of Business in Reutlingen, Germany; the Reims Management School, France; and the Universita degli Studi di Siena, Italy. Hofer's research interests focus primarily on logistics, supply chain management and aviation economics. His work has been published or is forthcoming in the Journal of Transport Economics and Policy, the Journal of the Transportation Research Forum, Transportation Research Part E: The Logistics and Transportation Review, and the Journal of Air Transport Management. Prior to returning to academia in 2003, he worked as a management consultant with Booz \& Company in Munich, Germany.

Martin Dresner has served on the faculty of the R.H. Smith School of Business at the University of Maryland since 1988, where he is currently professor of logistics and transportation. He received his Ph.D. in policy analysis from the University of British Columbia. Dresner's research focuses on two broad areas, air transport policy and logistics management. He has published papers in leading transportation, logistics, and supply chain journals, as well as in related fields. In addition, Dresner has co-authored a book on supply chain management. Professionally, he is editor of two journals, Research in Transportation Economics and Transportation Journal, and is active in several organizations, including stints as president of the Transportation and Public Utilities Group and the Transportation Research Forum. He has testified before the House Aviation Subcommittee, and has worked on consulting projects for a number of organizations, including the Maryland Aviation Administration and the U.S. Department of Energy. 